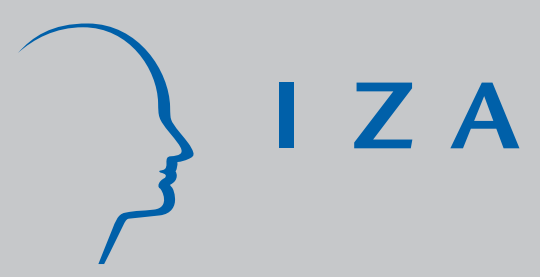

IZA DP No. 3359

Higher Wages in Exporting Firms: Self-Selection, Export Effect, or Both? First Evidence from German Linked Employer-Employee Data

Thorsten Schank

Claus Schnabel

J oachim Wagner

February 2008 


\title{
Higher Wages in Exporting Firms: Self-Selection, Export Effect, or Both? \\ First Evidence from German Linked Employer-Employee Data
}

\author{
Thorsten Schank \\ University of Erlangen-Nuremberg \\ Claus Schnabel \\ University of Erlangen-Nuremberg \\ and $I Z A$ \\ Joachim Wagner \\ University of Lueneburg \\ and IZA
}

Discussion Paper No. 3359

February 2008

IZA

P.O. Box 7240

53072 Bonn

Germany

Phone: +49-228-3894-0

Fax: +49-228-3894-180

E-mail: iza@iza.org

Any opinions expressed here are those of the author(s) and not those of IZA. Research published in this series may include views on policy, but the institute itself takes no institutional policy positions.

The Institute for the Study of Labor (IZA) in Bonn is a local and virtual international research center and a place of communication between science, politics and business. IZA is an independent nonprofit organization supported by Deutsche Post World Net. The center is associated with the University of Bonn and offers a stimulating research environment through its international network, workshops and conferences, data service, project support, research visits and doctoral program. IZA engages in (i) original and internationally competitive research in all fields of labor economics, (ii) development of policy concepts, and (iii) dissemination of research results and concepts to the interested public.

IZA Discussion Papers often represent preliminary work and are circulated to encourage discussion. Citation of such a paper should account for its provisional character. A revised version may be available directly from the author. 
IZA Discussion Paper No. 3359

February 2008

\section{ABSTRACT \\ Higher Wages in Exporting Firms: \\ Self-Selection, Export Effect, or Both? \\ First Evidence from German Linked Employer-Employee Data}

While it is a stylized fact that exporting firms pay higher wages than non-exporting firms, the direction of the link between exporting and wages is less clear. Using a rich set of German linked employer-employee panel data we follow over time plants that start to export. We show that the exporter wage premium does already exist in the years before firms start to export, and that it does not increase in the following years. Higher wages in exporting firms are thus due to self-selection of more productive, better paying firms into export markets; they are not caused by export activities.

JEL Classification: F10, D21, J31

Keywords: exports, wages, exporter wage premium, Germany

Corresponding author:

Claus Schnabel

Chair of Labour and Regional Economics

Friedrich-Alexander-University Erlangen-Nuremberg

Lange Gasse 20

D-90403 Nürnberg

Germany

E-mail: claus.schnabel@wiso.uni-erlangen.de 


\section{Motivation}

Exporting firms pay higher wages than firms that serve the national market only. This is one of the stylized facts from the emerging literature on the micro-econometrics of international firm activities. It was pointed out by Bernard and Jensen (1995) in their pioneering Brookings Paper, and it has been confirmed in a large number of studies (surveyed in Schank, Schnabel and Wagner, 2007) with firm level data from many different countries. Some recent studies using linked employer-employee data have demonstrated that this positive link between export activities and the level of wages paid by a firm can even be found after controlling for observed and unobserved characteristics of both the employer and the employees. $^{1}$

An issue that, to the best of our knowledge, has not been investigated empirically with linked employer-employee data is the sequencing behind the correlation of export activities and higher wages at the firm level. Does exporting lead to a wage premium? Or did exporting firms pay a wage premium even before they started to export? Theoretical considerations point to possible links in both directions that are by no means mutually exclusive:

- Hypothesis 1 (H1): The observed exporter wage premium reflects selfselection of more productive firms with higher wages into export markets. The recent literature on exporting by heterogeneous firms, pioneered by Melitz (2003) and surveyed by Greeneway and Kneller (2007), argues that only the more productive firms in an industry can bear the extra costs of entering foreign markets. In these models, exporters are more productive than non-exporters, and we observe selfselection of more productive firms into export activities, with the ex-ante more

\footnotetext{
${ }^{1}$ See Munch and Skaksen (2006) for Denmark, Alcalá and Hernández (2007) for Spain, and Schank, Schnabel and Wagner (2007) for Germany. Note, however, that Breau and Rigby (2006) find no wage difference between exporting and non-exporting plants after controlling for worker characteristics for the Los Angeles Consolidated Metropolitan Statistical Area.
} 
productive firms becoming exporters. If wages are higher in more productive firms due to higher profits and rent-sharing, or because higher (efficiency) wages cause higher productivity (see Akerlof and Yellen, 1986) ${ }^{2}$ - and if more productive firms self-select into export markets, we expect that these future exporters already paid a wage premium to the workers ex-ante, i.e. before they started to export.

- Hypothesis 2 (H2): Exporting makes firms more productive and leads to higher wages. This hypothesis found in the literature on exports and productivity points to the role of learning-by-exporting (see Bernard and Jensen, 1999, and Bernard and Wagner, 1997). Knowledge flows from international buyers and competitors help to improve the post-entry performance of export starters. Furthermore, firms participating in international markets are exposed to more intense competition and must improve faster than firms which only sell their products domestically. Exporting thus makes firms more productive. If wages are higher in more productive firms due to higher profits and rent-sharing, we may expect that exporting leads to higher wages. More specifically, this hypothesis predicts that after

\footnotetext{
${ }^{2}$ Egger and Kreikemeier (2007) develop a model that incorporates workers' fair wage preferences into a general equilibrium framework à la Melitz (2003). They modify the original Akerlof and Yellen (1990) fair wage - effort mechanism by introducing a rent-sharing motive as a determinant of workers' fair wage preferences, assuming that the wage considered to be fair depends, among others, on the productivity level and thus on the performance of the firm. Identical workers then earn different wages in equilibrium, and higher wages are paid to employees working in more productive firms. They refer to Fehr and Gächter (2000) who point out that the idea of gift exchange which is central to the fair wage - effort hypothesis implies exactly this. The theory of a positive correlation between productivity levels, profits and wages is well in line with empirical findings on rent-sharing in firms, as pointed out by Egger and Kreikemeier (2007). A different approach of introducing efficiency wages into heterogeneous firms models of the Melitz (2003) type is followed by Davis and Harrigan (2007) who argue that heterogeneity in the ability of firms to monitor effort leads to different wages for identical workers in equilibrium, following the variant of the efficiency wage theory put forward by Shapiro and Stiglitz (1984). If export starters are larger than non-exporters in the years before the start, and if monitoring costs are systematically higher in larger firms, this might lead to ex-ante wage differentials for identical workers in future export starters and non-exporters.
} 
a firm has started to export, the wages of its employees increase stronger than the wages of employees who work in firms that continue to produce for the national market only, leading to an ex-post exporter wage premium.

There is ample empirical evidence on the relationship between productivity and exporting, showing substantial exporter productivity premia and many findings in favor of the self-selection hypothesis, but much fewer results in favor of the learningby-exporting hypothesis. ${ }^{3}$ What is missing, however, are convincing empirical studies on the sequencing and the direction of the link between exporting and wages. One reason for this gap in the literature is the lack of suitable data. Since empirical studies of exporter wage differentials must control for observed and unobserved characteristics of both employers and employees that might determine wages besides exporting, they have to use linked employer-employee (LEE) panel data. To investigate the relevance of both the self-selection hypothesis and the learning-byexporting hypothesis in explaining exporter wage differentials, LEE data are needed which cover a period that is long enough to follow cohorts of firms over a couple of years before and after they start to export, and which can be used to test for ex-ante and ex-post wage differentials. Apparently, such LEE data were not available until recently.

Using suitable LEE data for Germany, a leading actor on the world market for goods, this paper contributes to the literature by testing the two hypotheses mentioned above on the direction of the link between exporting and wages. For the period 1994 to 2005, we show that the exporter wage premium does already exist in the years before firms start to export, and that it does not increase in the years after exporting started. According to our findings, higher wages in exporting firms are due

\footnotetext{
${ }^{3}$ See Wagner (2007) for a survey, and The International Study Group on Exports and Productivity (2007) for recent comparable results for 14 countries.
} 
to self-selection of more productive, better paying firms into export markets, but they are not caused by export activities.

The rest of the paper is organized as follows: Section 2 describes the LEE data. Section 3 presents the results of our empirical investigation, and section 4 concludes.

\section{The German linked employer-employee data}

The dataset used in the subsequent empirical analyses is the German LIAB, i.e. the linked employer-employee dataset of the Institute for Employment Research (Institut für Arbeitsmarkt- und Berufsforschung, IAB). The LIAB combines the Employment Statistics of the German Federal Employment Agency (Bundesagentur für Arbeit) with plant-level data from the IAB Establishment Panel. For detailed information on the LIAB, see Alda, Bender and Gartner (2005).

The employee side of our dataset is the Employment Statistics, covering all employees and trainees subject to social security. They exclude, among others, the self-employed, family workers, a subgroup of civil servants ("Beamte"), students enrolled in higher education, and those in marginal employment. The employment statistics cover nearly 80 percent of all employed persons in western Germany and about 85 percent of employees in eastern Germany. They are collected by the social insurance institutions for their purposes according to a procedure introduced in 1973 and are made available to the Federal Employment Agency. Notifications are prescribed at the beginning and at the end of a person's employment in a plant. In addition, an annual report for each employee is compulsory at the end of a year. Misreporting is legally sanctioned. The employment statistics contain information on an employee's occupation, the occupational status, and gross earnings up to the 
contribution assessment ceiling, ${ }^{4}$ as well as on individual characteristics like sex, age, nationality, marital status, and qualification. Each personnel record also contains the establishment identifier, the industry, and the size of the plant.

The employer side of our dataset is given by the IAB Establishment Panel, a random sample of establishments that is drawn from a stratified sample of the plants included in the Employment Statistics, where the strata are defined over industries and plant sizes (large plants are oversampled). In 1993, the panel started with 4,265 plants, covering 0.27 percent of all plants in western Germany ( 2 million) and 11 percent of total employment (29 million). In 1996, the establishment panel also started in eastern Germany with 4,313 establishments representing 1.1 percent of all plants $(391,000)$ and 11 percent of total employment (6 million). The IAB Establishment Panel has been set up for the needs of the Federal Employment Agency to provide further information about the demand side of the labor market. Therefore, detailed information on the composition of the workforce and its development through time constitutes a major part of the questionnaire. Further questions include information on training and further education, wages, working time, business activities, establishment policies, and general information about the plant.

The $L I A B$ is created by linking the Employment Statistics and the IAB Establishment Panel through a plant identifier which is available in both data sets. ${ }^{5}$

\footnotetext{
${ }^{4}$ For daily gross wages, the ceiling in 2000 , for example, is at $€ 143.92$ for western and at $€ 118.81$ for eastern Germany. In our regression sample, 8.2 (4.3) percent of the wage observations in western (eastern) Germany are censored. In order to cope with a potential bias due to censoring, we also conducted analyses not reported here (but available on request) which show that restricting the sample to uncensored observations does not change our conclusions.

${ }^{5}$ The LIAB data are confidential but not exclusive. They are available for non-commercial research by visiting the research data center of the German Federal Employment Agency at the IAB in Nuremberg, Germany. Researchers interested in replications or extensions of our work may contact the first author (e-mail: thorsten.schank@wiso.uni-erlangen.de) for a copy of the Stata do-files used to produce the results reported here.
} 
Because the Employment Statistics is spell-based (one record for each employment spell), the combined data is potentially complex. To simplify, we select all (full-time) workers in the employment statistics who are employed by the surveyed plants on June 30th in a year. This yields an unbalanced annual panel of workers together with detailed information on the plants in which they work, which is unique for Germany. We are able to use the years 1994 to 2005, and we focus on the private sector (excluding agriculture).

\section{Empirical investigation}

The core of our empirical strategy to test for the validity of the two hypotheses on export activities and higher wages consists in comparing over time wages in plants that start to export with wages in plants that continue to produce for the national market only. We start at a point in time when both groups of plants did not export, and end at a point in time when some of these firms have exported for a while. Using observation periods of six years, we define export starters as plants that do not export in the first three years $(t=1,2,3)$, but start to export in year $t=4$ and continue to export in the years $t=5$ and $t=6$; non-exporters are plants that do not export in any of the years $t=1, \ldots, 6$.

\subsection{Descriptive statistics}

Using the LIAB data described in Section 2 above, the six-year-windows considered here are 1994 to 1999,1995 to $2000, \ldots, 2000$ to 2005 . Data for export starters and non-exporters were pooled over these seven cohorts, and wages and sales were deflated. Table 1 reports descriptive statistics for both groups of plants and each year $t=1, \ldots, 6$. 


\section{[Table 1 near here]}

The sample available for our empirical investigation consists of 57 export starters and 3,139 non-exporters. A comparison of plants from both groups with regard to size (number of employees), labor productivity (sales per employee) and wages paid (average daily wage) reveals that export starters are on average larger, more productive, and better paying in each year. Compared to non-exporters, export starters have on average about three times the number of employees, and pay wages that are about 30 percent higher. However, while the difference in wages, which is the main focus of this study, is statistically highly significant, the difference in size is only marginally significant, and the difference in productivity is insignificant.

The descriptive statistics reported in Table 1 are in line with the first hypothesis $(H 1)$ according to which higher wages in exporting firms are due to selfselection of more productive and better paying firms into export markets - labor productivity and daily wages are higher in future export starters compared to nonexporters even in the years before the start (although the difference in average productivity is not statistically significant at any conventional level). In contrast, we find no evidence to support the second hypothesis $(H 2)$ which argues that exporting increases productivity and thus wages due to learning-by-exporting. Changes in labor productivity and in the daily wage between $t=3$ and $t=6$ do not differ in a statistically significant way between export starters and non-exporters.

\subsection{Plant level regressions}

While providing interesting information, the descriptive statistics reported in Table 1 cannot be considered as a basis for a convincing test of the two hypotheses $H 1$ and $H 2$. Since an exporter wage premium is a positive difference between the wages paid 
to employees in exporting and non-exporting firms after controlling for differences in other variables than exporting that determine wages, the rest of the empirical investigation is concerned with controlling for these influences on wages.

As a first step, we look at the difference in the plant average of daily wages between export starters and non-exporters over time, controlling for plant characteristics that can be expected to be related to the average wage level of a plant (including plant size, the presence or not of a works council, the use of new production technology, location in western or eastern Germany, various measures for the average qualification of the workforce, and dummies for industries, regions, and years). Results based on data for 3,196 plants are reported in column 1 of Table 2.

[Table 2 near here]

The coefficient of the exporter-starter dummy variable (see row 1 of Table 2) shows that the average daily wage paid by export starters is 7 percent higher than in a comparable non-exporting plant in $t=1$, i.e. three years before the export starts. This difference is both statistically significant and of a relevant order of magnitude from an economic point of view. ${ }^{6}$ Results reported in column 3 of Table 2 show that the same holds for labor productivity. Controlling for all plant characteristics used in the wage regression, the estimated productivity premium for export starters three years before the start is 19.8 percent. The statistically insignificant coefficients of the interaction terms of the export starter dummy variable and the dummy variables for $t$ $=2$ to $\mathrm{t}=6$ show that neither the difference in the average wage nor the difference in the average productivity changes over the years $t=2$ to $t=6$.

\footnotetext{
${ }^{6}$ The control variables all have the expected signs, and most of them are statistically significant. Since the focus of this paper is on the exporter wage premium, we do not comment on the results for the control variables here and in other regressions.
} 
These results are in line with our hypothesis $H 1$ - plants with higher wages (and a higher productivity) self-select into export markets. Contrary to this, hypothesis $\mathrm{H} 2$ - that wages (and productivity) increase after starting to export due to learningby-exporting effects - is not supported. Although in the wage regression and in the productivity regression five out of six point estimates of the interaction terms of the export starter dummy variable and the dummy variables for $\mathrm{t}=4 \mathrm{to} t=6$ are positive, none of them is statistically significantly different from zero at a usual error level. These findings are fully in line with the results from the descriptive statistics reported in Table 1.

Next, we apply an alternative approach to test for wage (and productivity) enhancing effects of starting to export. This is motivated by the problem that faster wage growth of plants which have just entered the export market (compared to plants that keep selling their products on the domestic market only) would not necessarily reflect a causal effect of exporting on wages. It could well be the case that better paying (and more productive) firms self-select into the export-starting group, but would have experienced higher wage growth even without starting to export. However, we cannot observe the latter scenario (i.e. the wage developments of today's export starters if they had not started to export), which is the well-known problem of the missing counterfactual situation. $^{7}$

This closely resembles a situation familiar from the evaluation of active labor market programs (or any other form of treatment of units): If participants, or treated units, are not selected randomly from a population but are selected or self-select according to certain criteria, the effect of a treatment cannot be evaluated by comparing the average performance of the treated and the non-treated. Since each

\footnotetext{
${ }^{7}$ Although the regression results discussed above do not show a difference in wage growth between export starters and non-starters, these estimates may be biased due to the self-selection of export starters.
} 
unit (plant or person) either did participate or not, we lack the required information about its performance in the counterfactual situation. A way out is to construct a control group in such a way that every treated unit is matched to an untreated unit that was as similar as possible (ideally, identical) at the time before the treatment. Differences between the two groups (the treated, and the matched non-treated) after the treatment can then be attributed to the treatment (for a comprehensive discussion, see Heckman, LaLonde and Smith, 1999). The use of a matching approach to search for effects of starting to export on wages (and other dimensions of firm performance, including productivity) has been pioneered by Wagner (2002), and it has been used in a growing number of empirical studies (surveyed in Wagner, 2007) ever since.

In the present study, export starters in year $\mathrm{t}=4$ were matched with "statistical twins" from the large group of non-exporters, based on characteristics of the plants in $t=1$ (three years before the starters begin to export). Matching was implemented by nearest neighbour propensity score matching. ${ }^{8}$ The propensity score was estimated from a probit regression of a dummy variable indicating whether or not a plant is an export starter in year $t=4$ on a set of variables (all measured at $t=1$ ) that are considered as determinants of the probability to start to export and are related to the average wage paid in the firm. Details are given in Table A1 in the Appendix. The balancing property (which requires an absence of statistically significant differences between the treatment group and the control group in the covariates after matching) is satisfied. The differences in the means of the variables used to compute the propensity score were never statistically significant between the starters and the matched non-starters (see Table A2 in the Appendix). The common support condition

\footnotetext{
${ }^{8}$ Alternative matching procedures have also been carried out (using three and five nearest neighbors, kernel matching), but the (unreported) results were similar to those discussed in the next section.
} 
(which requires that the propensity score of a treated observation is neither higher than the maximum nor less than the minimum propensity score of the controls) was imposed by dropping export starters whose propensity score is higher than the maximum or lower than the minimum propensity score of the non-exporters.

This matching approach leads to 48 (out of 57) export starters for which a nonexporting twin-plant could be found. These 48 pairs constitute our so-called matched sample made up of 96 plants. The plant-level regressions of average daily wages and of sales per employee discussed above were repeated for data from this matched sample; results are reported in columns 2 and 4 of Table 2. By construction (due to the successful matching) neither wages nor productivity differ significantly between export starters and non-exporting plants in $t=1$, and the same holds for the other years before the export start in $t=4$.

In the matched sample, the estimated regression coefficients of the interaction terms of the export starter dummy variable with the dummy variables for the years $t=$ $4, t=5$ and $t=6$ turn out to be statistically insignificant at any conventional level in both the wage and the productivity regression. Therefore, in line with the findings from the descriptive statistics reported in Table 1 and from the regressions using the full sample of plants reported in columns 1 and 3 of Table 2, we find no evidence for hypothesis $H 2$ which argues that exporting increases productivity and thus wages due to learning-by-exporting.

\subsection{Individual level wage regressions}

The plant level estimations presented in Section 3.2 may suffer from aggregation bias since individual heterogeneity which influences wages cannot be controlled for. Therefore, we replicate the empirical investigation for wages using data at the individual level, controlling for both observed employer and employee 
characteristics. ${ }^{9}$ Like in the plant level analysis we consider two samples of plants the full sample of all plants, and the matched sample made up of export starters and matched non-exporters.

We also take into account that the selection effect only controls for timeinvariant differences between export starters and non-starters and their employees. Any changes in the workforce (due to hirings and separations) are by definition not absorbed by the selection effect. If quitters and joiners are non-random with respect to the introduction of the export activity, we may obtain a biased estimate of our hypothesis H2. We control for this by (additionally) looking only at wages of individuals who remain in the respective plant in all six years observed (stayers).

[Table 3 near here]

Results for the full sample of 3,196 plants and all 351,157 employees, meaning a total of $1,270,089$ observations, are reported in column 1 of Table 3 . The estimated coefficient of the export starter dummy variable is positive and highly statistically significant. It is also large from an economic point of view, pointing to an export starter wage differential of 9 percent in $t=1$ (i.e. three years before the start). Although this differential reduces slightly in $t=2$, these results are strongly in favor of hypothesis $H 1$ according to which higher wages in exporting firms are due to selfselection of better paying firms into export markets. This finding is corroborated by the results for the same empirical model estimated for stayers only (see column 2 of Table 3), where an export starter wage premium of 7.7 percent is found. ${ }^{10}$

\footnotetext{
${ }^{9}$ Due to the lack of information for productivity at the individual level this replication is possible for the wage equations only.

${ }^{10}$ As before, the control variables all have the expected signs, and most of them are statistically significant.
} 
In contrast, hypothesis H2 (according to which wages and productivity increase after starting to export due to learning-by-exporting effects) is not supported by our data. Neither in the estimations based on all employees nor in the regressions including stayers only the interaction terms of the export starter dummy variable and the dummy variables for the years $t=4, t=5$ and $t=6$ are ever positive and statistically significant. In fact, five of the six coefficients are negative, and wages do even decrease in the year of the export start compared to wages earned by employees with the same characteristics in plants with the same characteristics which continue to produce for the national market only.

Finally, we turn to the results for all employees and for the stayers in the matched sample. These are reported in columns 3 and 4, respectively, of Table 3. Again, we do not find any empirical evidence in favor of a wage increase after starting to export. Higher wages in exporting plants thus do not seem to be induced by export activities.

\section{Conclusions}

Using a rich set of German linked employer-employee panel data, we have demonstrated that the exporter wage premium does already exist in the years before plants start to export, and that it does not increase in the years after exporting started. According to our results, higher wages in exporting plants that are found after controlling for observed and unobserved employer and employee characteristics are due to self-selection of more productive, better paying plants into export markets. This empirical finding is in accordance with the recent theoretical literature on exporting by heterogeneous firms (pioneered by Melitz 2003) which postulates that only the more productive firms in an industry can bear the extra costs of entering foreign markets. 
Our empirical results imply that the so-called exporter wage premium is labeled misleadingly since it may not be caused by export activities. At least in the case of Germany, one of the major exporting countries in the world, exporting does not seem to make firms more productive and lead to higher wages. It would be interesting to see whether this finding can be replicated for other countries using linked employer-employee panel data. These sort of data provide information that should be tapped more intensively in order to gain additional insights in international firm activities.

\section{References}

Akerlof, G. A., Yellen, J. L. (eds.), 1986. Efficiency wage models of the labor market. Cambridge University Press, Cambridge, England.

Akerlof, G. A., Yellen, J. L., 1990. The fair wage - effort hypothesis and unemployment. Quarterly Journal of Economics 105, 255-283.

Alcalá, F., Hernández, P. J., 2007. Firm characteristics, labor sorting, and wages. Universidad de Murcia, mimeo, January.

Alda, H., Bender, S., Gartner, H., 2005. The linked employer-employee dataset created from the IAB establishment panel and the process-produced data of the IAB (LIAB). Schmollers Jahrbuch / Journal of Applied Social Science Studies 125, 327-336.

Bernard, A. B., Jensen, J. B., 1995. Exporters, jobs, and wages in U.S. manufacturing: 1976-1987. Brookings Papers on Economic Activity. Microeconomics 67-119.

Bernard, A. B., Jensen, J. B., 1999. Exceptional exporter performance: Cause, effect, or both? Journal of International Economics 47, 1-25. 
Bernard, A. B., Wagner, J., 1997. Exports and success in German manufacturing. Weltwirtschaftliches Archiv / Review of World Economics 133, 134-157.

Breau, S., Rigby, D. L., 2006. Is there really an export wage premium? A case study of Los Angeles using matched employee-employer data. Center for Economic Studies, Bureau of the Census, Washington, DC, Working Paper CES 06-06, February.

Davis, D. R., Harrigan, J., 2007. Good Jobs, bad jobs, and trade liberalization. National Bureau of Economic Research Working Paper 13139, May.

Egger, H., Kreikemeier, U., 2007. Firm heterogeneity and the labour market effects of trade liberalisation. CESifo Working Paper No. 2000, May.

Fehr, E., Gächter, S., 2000. Fairness and Retaliation: The economics of reciprocity. Journal of Economic Perspectives 14, 159-181.

Greenaway, D., Kneller, D., 2007. Firm heterogeneity, exporting and foreign direct investment: A survey. Economic Journal 117, F134-F161.

Heckman, J. J., LaLonde, R. J., Smith, J. A., 1999. The economics and econometrics of active labor market programs. In: Ashenfelter, O. C., Card, D. (Eds.), Handbook of Labor Economics, Vol. 3A, Amsterdam: North-Holland, 18652097.

Melitz, M. J., 2003. The impact of trade on intra-industry reallocations and aggregate industry productivity. Econometrica $71,1695-1725$.

Munch, J. R., Skaksen, J. R., 2006. Human capital and wages in exporting firms. Institute for the Study of Labor IZA Discussion Paper 2409, October.

Schank, T., Schnabel, C., Wagner, J., 2007. Do exporters really pay higher wages? First evidence from German linked employer-employee data. Journal of International Economics 72, 52-72. 
Shapiro, C., Stiglitz, J. E., 1984. Equilibrium unemployment as a worker discipline device. American Economic Review 74, 433-444.

The International Study Group on Exports and Productivity, 2007. Exports and productivity - Comparable evidence for 14 countries. University of Lüneburg Working Paper Series in Economics No. 65, November.

Wagner, J., 2002. The causal effect of exports on firm size and labor productivity: First evidence from a matching approach. Economics Letters 77, 287-292.

Wagner, J., 2007. Exports and productivity: A survey of the evidence from firm-level data. The World Economy 30, 60-82. 
Table 1: Descriptive statistics for export starters and non-exporters, all plants

\begin{tabular}{crrr}
\hline & $\begin{array}{r}\text { Export starters } \\
(N=57)\end{array}$ & $\begin{array}{r}\text { Non-exporters } \\
(N=3,139)\end{array}$ & $\begin{array}{r}\text { Prob-value for } \mathrm{H}_{0}: \\
\text { Diff. of means }=0\end{array}$ \\
\hline $\begin{array}{l}\text { Plant size } \\
\text { (number of persons) }\end{array}$ & & & \\
$\mathrm{t}=1$ & 319.32 & 109.27 & 0.07 \\
$\mathrm{t}=2$ & 312.35 & 104.68 & 0.06 \\
$\mathrm{t}=3$ & 289.19 & 101.84 & 0.07 \\
$\mathrm{t}=4$ & 289.04 & 99.66 & 0.06 \\
$\mathrm{t}=5$ & 288.68 & 97.65 & 0.05 \\
$\mathrm{t}=6$ & 270.90 & 95.05 & 0.06
\end{tabular}

Yearly sales per employee

(in thousands of $€$ )

$\begin{array}{llll}\mathrm{t}=1 & 140.69 & 120.87 & 0.25 \\ \mathrm{t}=2 & 146.47 & 121.72 & 0.29 \\ \mathrm{t}=3 & 146.25 & 119.16 & 0.19 \\ \mathrm{t}=4 & 134.94 & 121.33 & 0.36 \\ \mathrm{t}=5 & 127.32 & 122.38 & 0.76 \\ \mathrm{t}=6 & 150.75 & 125.98 & 0.36\end{array}$

Average daily wage (in $€$ )

$\begin{array}{llll}\mathrm{t}=1 & 77.75 & 60.32 & 0.00 \\ \mathrm{t}=2 & 77.86 & 60.34 & 0.00 \\ \mathrm{t}=3 & 79.81 & 61.12 & 0.00 \\ \mathrm{t}=4 & 79.98 & 61.46 & 0.00 \\ \mathrm{t}=5 & 79.81 & 61.22 & 0.00 \\ \mathrm{t}=6 & 79.96 & 60.62 & 0.00\end{array}$

Growth rates between

$\mathrm{t}=3$ and $\mathrm{t}=6$, in $\%$

Plant size

(number of persons)

Yearly sales per

employee

(in thousands of $€$ )
27.42

1.40

$-0.01$
$-0.65$

0.22

8.58

0.27

Average daily wage (in €)

Sample is lower for sales per employee due to missing values. Export starters are plants which do not export in the first three years $(t=1,2,3)$, but export in the last three years $(t=$ $4,5,6)$. Non-exporters do not export in any year. Wages and sales are deflated by the aggregate consumer price index. $t=1, \ldots, 6$ refers to a specific year in the 6 -year-window a plant is observed. Start (end) years for these windows vary across plants between 1994 (1999) and 2000 (2005). 
Table 2: Plant-level regressions of wages and labor productivity (OLS); Germany

\begin{tabular}{|c|c|c|c|c|}
\hline \multirow{2}{*}{$\begin{array}{l}\text { Dependent variable: } \\
\text { Explanatory variables }\end{array}$} & \multicolumn{2}{|c|}{$\begin{array}{l}\text { Logarithm of (plant } \\
\text { average of) daily wage }\end{array}$} & \multicolumn{2}{|c|}{$\begin{array}{c}\text { Logarithm of sales per } \\
\text { employee }\end{array}$} \\
\hline & $\begin{array}{l}\text { Full } \\
\text { sample }\end{array}$ & $\begin{array}{l}\text { Matched } \\
\text { sample }\end{array}$ & $\begin{array}{l}\text { Full } \\
\text { sample }\end{array}$ & $\begin{array}{l}\text { Matched } \\
\text { sample }\end{array}$ \\
\hline Export starter (dummy: 1 = yes) & $\begin{array}{l}0.070 \\
{[2.55]^{\star \star}}\end{array}$ & $\begin{array}{l}-0.024 \\
{[0.80]}\end{array}$ & $\begin{array}{l}0.198 \\
{[2.44]^{\star \star}}\end{array}$ & $\begin{array}{l}-0.023 \\
{[0.18]}\end{array}$ \\
\hline Dummy $(t=2) \times$ export starter & $\begin{array}{l}0.000 \\
{[0.00]}\end{array}$ & $\begin{array}{l}0.010 \\
{[0.61]}\end{array}$ & $\begin{array}{l}0.022 \\
{[0.39]}\end{array}$ & $\begin{array}{l}0.038 \\
{[0.44]}\end{array}$ \\
\hline Dummy $(t=3) \times$ export starter & $\begin{array}{l}-0.005 \\
{[0.37]}\end{array}$ & $\begin{array}{l}-0.008 \\
{[0.37]}\end{array}$ & $\begin{array}{l}0.033 \\
{[0.46]}\end{array}$ & $\begin{array}{l}0.040 \\
{[0.42]}\end{array}$ \\
\hline Dummy $(t=4) \times$ export starter & $\begin{array}{l}0.006 \\
{[0.48]}\end{array}$ & $\begin{array}{l}0.000 \\
{[0.00]}\end{array}$ & $\begin{array}{l}0.038 \\
{[0.67]}\end{array}$ & $\begin{array}{l}0.104 \\
{[1.04]}\end{array}$ \\
\hline Dummy $(t=5) \times$ export starter & $\begin{array}{l}0.012 \\
{[0.83]}\end{array}$ & $\begin{array}{l}0.010 \\
{[0.42]}\end{array}$ & $\begin{array}{l}-0.003 \\
{[0.04]}\end{array}$ & $\begin{array}{l}0.104 \\
{[0.94]}\end{array}$ \\
\hline Dummy $(t=6) \times$ export starter & $\begin{array}{l}0.010 \\
{[0.64]}\end{array}$ & $\begin{array}{l}-0.006 \\
{[0.23]}\end{array}$ & $\begin{array}{l}0.049 \\
{[0.50]}\end{array}$ & $\begin{array}{l}0.184 \\
{[1.44]}\end{array}$ \\
\hline $\begin{array}{l}\text { Logarithm of establishment size } \\
\text { (number of employees) }\end{array}$ & $\begin{array}{l}0.117 \\
{[10.34]^{\star \star \star}}\end{array}$ & $\begin{array}{l}-0.011 \\
{[0.15]}\end{array}$ & $\begin{array}{l}-0.011 \\
{[0.34]}\end{array}$ & $\begin{array}{l}-0.154 \\
{[0.73]}\end{array}$ \\
\hline $\begin{array}{l}\text { Squared logarithm of } \\
\text { establishment size }\end{array}$ & $\begin{array}{l}-0.011 \\
{[8.00]^{\star \star *}}\end{array}$ & $\begin{array}{l}0.001 \\
{[0.09]}\end{array}$ & $\begin{array}{l}-0.006 \\
{[1.58]}\end{array}$ & $\begin{array}{l}0.006 \\
{[0.27]}\end{array}$ \\
\hline $\begin{array}{l}\text { Works council } \\
\text { (dummy: } 1 \text { = yes) } \\
\text { Collective agreement } \\
\text { (reference: no collective } \\
\text { agreement) }\end{array}$ & $\begin{array}{l}0.086 \\
{[8.53]^{\star \star \star}}\end{array}$ & $\begin{array}{l}-0.071 \\
{[1.86]^{*}}\end{array}$ & $\begin{array}{l}0.250 \\
{[7.11]^{\star \star \star}}\end{array}$ & $\begin{array}{l}0.035 \\
{[0.26]}\end{array}$ \\
\hline $\begin{array}{l}\text { at sectoral level } \\
\text { (dummy: } 1=\text { yes) }\end{array}$ & $\begin{array}{l}0.065 \\
{[8.65]^{\star \star \star}}\end{array}$ & $\begin{array}{l}-0.022 \\
{[1.02]}\end{array}$ & $\begin{array}{l}0.051 \\
{[2.19]^{\star \star}}\end{array}$ & $\begin{array}{l}-0.014 \\
{[0.17]}\end{array}$ \\
\hline $\begin{array}{l}\text { at firm level } \\
\text { (dummy: } 1=\text { yes) }\end{array}$ & $\begin{array}{l}0.048 \\
{[5.17]^{\star \star \star}}\end{array}$ & $\begin{array}{l}-0.004 \\
{[0.22]}\end{array}$ & $\begin{array}{l}0.061 \\
{[1.79]^{\star}}\end{array}$ & $\begin{array}{l}0.088 \\
{[0.95]}\end{array}$ \\
\hline $\begin{array}{l}\text { Plant belongs to a larger unit } \\
\text { (dummy: } 1=\text { yes) }\end{array}$ & $\begin{array}{l}0.107 \\
{[8.66]^{\star \star \star}}\end{array}$ & $\begin{array}{l}0.101 \\
{[2.89]^{\star \star \star}}\end{array}$ & $\begin{array}{l}0.350 \\
{[7.80]^{\star \star \star}}\end{array}$ & $\begin{array}{l}0.623 \\
{[4.74]^{\star \star \star}}\end{array}$ \\
\hline $\begin{array}{l}\text { New production technology } \\
\text { (dummy: } 1=\text { yes) } \\
\text { Eastern Germany } \\
\text { (dummy: } 1 \text { = yes) }\end{array}$ & $\begin{array}{l}0.041 \\
{[7.37]^{\star \star \star}} \\
-0.232 \\
{[7.91]^{\star \star \star}}\end{array}$ & $\begin{array}{l}0.033 \\
{[1.78]^{\star}} \\
-0.423 \\
{[4.78]^{\star \star \star}}\end{array}$ & $\begin{array}{l}0.126 \\
{[7.02]^{\star \star \star}} \\
0.048 \\
{[0.50]}\end{array}$ & $\begin{array}{l}0.046 \\
{[0.63]} \\
0.367 \\
{[1.16]}\end{array}$ \\
\hline $\begin{array}{l}\text { Average age of employees } \\
\text { (in years) }\end{array}$ & $\begin{array}{l}-0.004 \\
{[0.76]}\end{array}$ & $\begin{array}{l}0.032 \\
{[0.94]}\end{array}$ & $\begin{array}{l}0.025 \\
{[1.46]}\end{array}$ & $\begin{array}{l}0.038 \\
{[0.35]}\end{array}$ \\
\hline $\begin{array}{l}\text { Average age squared } \\
\text { (divided by 100) }\end{array}$ & $\begin{array}{l}0.008 \\
{[1.01]}\end{array}$ & $\begin{array}{l}-0.040 \\
{[0.91]}\end{array}$ & $\begin{array}{l}-0.035 \\
{[1.62]}\end{array}$ & $\begin{array}{l}-0.053 \\
{[0.38]}\end{array}$ \\
\hline Average tenure of employees & $\begin{array}{l}0.025 \\
{[7.66]^{\star \star \star}}\end{array}$ & $\begin{array}{l}-0.001 \\
{[0.05]}\end{array}$ & $\begin{array}{l}0.055 \\
{[6.17]^{\star \star \star}}\end{array}$ & $\begin{array}{l}0.156 \\
{[3.05]^{\star \star \star}}\end{array}$ \\
\hline $\begin{array}{l}\text { Average tenure squared } \\
\text { (divided by 100) } \\
\text { Proportion within total workforce } \\
\text { of plant: }\end{array}$ & $\begin{array}{l}-0.099 \\
{[4.93]^{\star \star \star}}\end{array}$ & $\begin{array}{l}0.058 \\
{[0.81]}\end{array}$ & $\begin{array}{l}-0.246 \\
{[5.32]^{\star \star \star}}\end{array}$ & $\begin{array}{l}-0.672 \\
{[2.45]^{\star \star}}\end{array}$ \\
\hline Female workers & $\begin{array}{l}-0.299 \\
{[15.47]^{\star \star \star}}\end{array}$ & $\begin{array}{l}-0.313 \\
{[4.50]^{\star \star \star}}\end{array}$ & $\begin{array}{l}-0.190 \\
{[3.37]^{\star \star \star}}\end{array}$ & $\begin{array}{l}-0.751 \\
{[2.97]^{\star \star \star}}\end{array}$ \\
\hline Non-German workers & $\begin{array}{l}-0.126 \\
{[2.59]^{\star \star \star}}\end{array}$ & $\begin{array}{l}0.055 \\
{[0.37]}\end{array}$ & $\begin{array}{l}-0.204 \\
{[2.40]^{\star \star}}\end{array}$ & $\begin{array}{l}0.464 \\
{[0.65]}\end{array}$ \\
\hline $\begin{array}{l}\text { Workers with apprenticeship, } \\
\text { no Abitur } \\
\text { Workers without } \\
\text { apprenticeship, with Abitur }\end{array}$ & $\begin{array}{l}0.094 \\
{[3.48]^{\star \star \star}} \\
0.116 \\
{[0.76]}\end{array}$ & $\begin{array}{l}0.324 \\
{[2.12]^{\star \star}} \\
-0.389 \\
{[0.59]}\end{array}$ & $\begin{array}{l}0.148 \\
{[1.99]^{\star \star}} \\
0.259 \\
{[1.49]}\end{array}$ & $\begin{array}{l}0.005 \\
{[0.01]} \\
9.090 \\
{[3.48]^{\star \star \star}}\end{array}$ \\
\hline
\end{tabular}




\begin{tabular}{lllll}
\hline Workers with apprenticeship & 0.300 & 1.131 & 0.351 & 0.458 \\
and Abitur & {$[5.19]^{\star \star \star}$} & {$[3.86]^{\star \star \star}$} & {$[2.21]^{\star \star}$} & {$[0.38]$} \\
Workers with technical college & 0.581 & 0.332 & 0.925 & -0.422 \\
degree & {$[10.33]^{\star \star \star}$} & {$[1.90]^{\star}$} & {$[4.82]^{\star \star \star}$} & {$[0.68]$} \\
Workers with university & 0.615 & 1.236 & 0.766 & 0.246 \\
degree & {$[11.95]^{\star \star \star}$} & {$[4.91]^{\star \star \star}$} & {$[4.40]^{\star \star \star}$} & {$[0.28]$} \\
Workers with unreported & 0.086 & 0.170 & 0.195 & -0.329 \\
education & {$[3.00]^{\star \star \star}$} & {$[1.21]$} & {$[2.46]^{\star \star}$} & {$[0.64]$} \\
Master craftsman & 0.106 & 0.243 & -0.043 & -0.304 \\
Constant & {$[1.93]^{\star}$} & {$[0.73]$} & {$[0.26]$} & {$[0.26]$} \\
& 3.646 & 4.100 & 10.929 & 10.360 \\
Observations & {$[31.60]^{\star \star \star}$} & {$[5.30]^{\star \star \star}$} & {$[33.75]^{\star \star \star}$} & {$[4.28]^{\star \star \star}$} \\
Plants & & & & \\
$\mathrm{R}^{2}$ & 18,800 & 576 & 16,723 & 542 \\
\hline Regressions & 3,196 & 96 & 3,077 & 96 \\
\hline
\end{tabular}

Regressions also include 36 sectoral dummies, 9 urbanisation dummies, 15 regional dummies, 11 year dummies as well as 5 dummies for the respective periods $t$. |t|-statistics in parentheses, based on robust standard errors adjusted for clustering at the plant-level. Full sample refers to all observations with no missing values in the covariates. Matched sample refers to observations from plants which have been selected via nearest neighbor propensity score matching, where the propensity score has been obtained from a probit on exportstarting. 
Table 3: Individual level wage regressions (OLS); Germany (Dependent variable: logarithm of daily wage)

\begin{tabular}{|c|c|c|c|c|}
\hline & \multicolumn{2}{|c|}{ Full sample } & \multicolumn{2}{|c|}{ Matched sample } \\
\hline Explanatory variables & All & Stayers & All & Stayers \\
\hline Export starter (dummy: 1 = yes) & $\begin{array}{l}0.089 \\
{[3.74]^{\star \star \star}}\end{array}$ & $\begin{array}{l}0.077 \\
{[3.58]^{\star \star \star}}\end{array}$ & $\begin{array}{l}0.003 \\
{[0.13]}\end{array}$ & $\begin{array}{l}0.021 \\
{[0.81]}\end{array}$ \\
\hline Dummy $(\mathrm{t}=2) \times$ export starter & $\begin{array}{l}-0.011 \\
{[2.43]^{\star \star}}\end{array}$ & $\begin{array}{l}-0.004 \\
{[0.93]}\end{array}$ & $\begin{array}{l}0.013 \\
{[1.08]}\end{array}$ & $\begin{array}{l}0.018 \\
{[1.55]}\end{array}$ \\
\hline Dummy $(t=3) \times$ export starter & $\begin{array}{l}-0.002 \\
{[0.31]}\end{array}$ & $\begin{array}{l}0.001 \\
{[0.20]}\end{array}$ & $\begin{array}{l}0.025 \\
{[1.80]^{*}}\end{array}$ & $\begin{array}{l}0.017 \\
{[1.21]}\end{array}$ \\
\hline Dummy $(t=4) \times$ export starter & $\begin{array}{l}-0.021 \\
{[2.08]^{\star \star}}\end{array}$ & $\begin{array}{l}-0.028 \\
{[2.09]^{\star \star}}\end{array}$ & $\begin{array}{l}-0.009 \\
{[0.73]}\end{array}$ & $\begin{array}{l}-0.019 \\
{[1.33]}\end{array}$ \\
\hline Dummy $(t=5) \times$ export starter & $\begin{array}{l}-0.014 \\
{[1.53]}\end{array}$ & $\begin{array}{l}-0.013 \\
{[1.54]}\end{array}$ & $\begin{array}{l}-0.008 \\
{[0.75]}\end{array}$ & $\begin{array}{l}-0.015 \\
{[1.22]}\end{array}$ \\
\hline Dummy $(t=6) \times$ export starter & $\begin{array}{l}0.002 \\
{[0.21]}\end{array}$ & $\begin{array}{l}-0.009 \\
{[0.83]}\end{array}$ & $\begin{array}{l}-0.006 \\
{[0.42]}\end{array}$ & $\begin{array}{l}-0.012 \\
{[0.78]}\end{array}$ \\
\hline $\begin{array}{l}\text { Logarithm of establishment size } \\
\text { (number of employees) }\end{array}$ & $\begin{array}{l}0.035 \\
{[2.11]^{\star \star}}\end{array}$ & $\begin{array}{l}0.066 \\
{[4.91]^{\star \star \star}}\end{array}$ & $\begin{array}{l}-0.083 \\
{[1.30]}\end{array}$ & $\begin{array}{l}-0.038 \\
{[0.45]}\end{array}$ \\
\hline $\begin{array}{l}\text { Squared logarithm of } \\
\text { establishment size }\end{array}$ & $\begin{array}{l}-0.003 \\
{[1.52]}\end{array}$ & $\begin{array}{l}-0.004 \\
{[2.84]^{\star \star \star}}\end{array}$ & $\begin{array}{l}0.007 \\
{[1.32]}\end{array}$ & $\begin{array}{l}0.003 \\
{[0.40]}\end{array}$ \\
\hline $\begin{array}{l}\text { Works council } \\
\text { (dummy: } 1=\text { yes) }\end{array}$ & $\begin{array}{l}0.111 \\
{[6.94]^{\star \star \star}}\end{array}$ & $\begin{array}{l}0.079 \\
{[5.42]^{\star \star \star}}\end{array}$ & $\begin{array}{l}0.018 \\
{[0.50]}\end{array}$ & $\begin{array}{l}0.020 \\
{[0.49]}\end{array}$ \\
\hline $\begin{array}{l}\text { Collective agreement } \\
\text { (reference: no collective } \\
\text { agreement) }\end{array}$ & & & & \\
\hline $\begin{array}{l}\text { at sectoral level } \\
\text { (dummy: } 1=\text { yes) }\end{array}$ & $\begin{array}{l}0.012 \\
{[0.74]}\end{array}$ & $\begin{array}{l}0.021 \\
{[1.63]}\end{array}$ & $\begin{array}{l}-0.047 \\
{[2.00]^{\star \star}}\end{array}$ & $\begin{array}{l}-0.039 \\
{[1.57]}\end{array}$ \\
\hline $\begin{array}{l}\text { at firm level } \\
\text { (dummy: } 1=\text { yes) }\end{array}$ & $\begin{array}{l}-0.002 \\
{[0.14]}\end{array}$ & $\begin{array}{l}0.006 \\
{[0.40]}\end{array}$ & $\begin{array}{l}-0.031 \\
{[1.57]}\end{array}$ & $\begin{array}{l}-0.023 \\
{[1.19]}\end{array}$ \\
\hline $\begin{array}{l}\text { Plant belongs to a larger unit } \\
\text { (dummy: } 1=\text { yes) }\end{array}$ & $\begin{array}{l}0.054 \\
{[3.77]^{\star \star \star}}\end{array}$ & $\begin{array}{l}0.039 \\
{[2.55]^{\star \star}}\end{array}$ & $\begin{array}{l}0.084 \\
{[4.51]^{\star \star \star}}\end{array}$ & $\begin{array}{l}0.088 \\
{[4.91]^{\star \star \star}}\end{array}$ \\
\hline $\begin{array}{l}\text { New production technology } \\
\text { (dummy: } 1 \text { = yes) }\end{array}$ & $\begin{array}{l}0.022 \\
{[3.30]^{\star \star *}}\end{array}$ & $\begin{array}{l}0.016 \\
{[2.73]^{\star \star \star}}\end{array}$ & $\begin{array}{l}0.014 \\
{[1.28]}\end{array}$ & $\begin{array}{l}0.002 \\
{[0.20]}\end{array}$ \\
\hline $\begin{array}{l}\text { Eastern Germany } \\
\text { (dummy: } 1 \text { = yes) }\end{array}$ & $\begin{array}{l}-0.264 \\
{[5.93]^{\star \star \star}}\end{array}$ & $\begin{array}{l}-0.246 \\
{[8.49]^{\star \star \star}}\end{array}$ & $\begin{array}{l}-0.225 \\
{[3.39]^{\star \star \star}}\end{array}$ & $\begin{array}{l}-0.435 \\
{[5.96]^{\star \star \star}}\end{array}$ \\
\hline Age of employee (in years) & $\begin{array}{l}0.026 \\
{[27.13]^{\star \star \star}}\end{array}$ & $\begin{array}{l}0.021 \\
{[16.25]^{\star * *}}\end{array}$ & $\begin{array}{l}0.020 \\
{[7.14]^{\star \star \star}}\end{array}$ & $\begin{array}{l}0.012 \\
{[4.26]^{\star \star \star}}\end{array}$ \\
\hline Age squared (divided by 100 ) & $\begin{array}{l}-0.028 \\
{[26.37]^{\star \star \star}}\end{array}$ & $\begin{array}{l}-0.023 \\
{[15.28]^{\star \star \star}}\end{array}$ & $\begin{array}{l}-0.020 \\
{[6.59]^{\star \star \star}}\end{array}$ & $\begin{array}{l}-0.012 \\
{[3.96]^{\star \star \star}}\end{array}$ \\
\hline Tenure of employee (in years) & $\begin{array}{l}0.020 \\
{[11.54]^{\star \star *}}\end{array}$ & $\begin{array}{l}0.008 \\
{[5.86]^{\star \star *}}\end{array}$ & $\begin{array}{l}0.016 \\
{[6.21]^{\star \star \star}}\end{array}$ & $\begin{array}{l}0.010 \\
{[3.63]^{\star \star \star}}\end{array}$ \\
\hline Tenure squared (divided by 100 ) & $\begin{array}{l}-0.050 \\
{[9.40]^{\star \star \star}}\end{array}$ & $\begin{array}{l}-0.009 \\
{[2.41]^{\star \star}}\end{array}$ & $\begin{array}{l}-0.034 \\
{[4.38]^{\star \star \star}}\end{array}$ & $\begin{array}{l}-0.012 \\
{[1.76]^{\star}}\end{array}$ \\
\hline Female (dummy: 1 = yes) & $\begin{array}{l}-0.140 \\
{[14.48]^{\star \star \star}}\end{array}$ & $\begin{array}{l}-0.124 \\
{[16.14]^{\star \star \star}}\end{array}$ & $\begin{array}{l}-0.114 \\
{[8.72]^{\star \star \star}}\end{array}$ & $\begin{array}{l}-0.096 \\
{[6.06]^{\star \star *}}\end{array}$ \\
\hline Non-German (dummy: 1 = yes) & $\begin{array}{l}-0.079 \\
{[5.00]^{\star \star \star}}\end{array}$ & $\begin{array}{l}-0.059 \\
{[4.66]^{\star \star \star}}\end{array}$ & $\begin{array}{l}-0.051 \\
{[4.04]^{\star \star \star}}\end{array}$ & $\begin{array}{l}-0.043 \\
{[3.79]^{\star \star \star}}\end{array}$ \\
\hline $\begin{array}{l}\text { Without apprenticeship or Abitur } \\
\text { (ref. group) }\end{array}$ & & & & \\
\hline $\begin{array}{l}\text { Apprenticeship, no Abitur } \\
\text { (dummy: } 1 \text { = yes) }\end{array}$ & $\begin{array}{l}0.103 \\
{[10.10]^{\star \star \star}}\end{array}$ & $\begin{array}{l}0.087 \\
{[7.53]^{\star \star \star}}\end{array}$ & $\begin{array}{l}0.115 \\
{[6.83]^{\star \star \star}}\end{array}$ & $\begin{array}{l}0.111 \\
{[6.73]^{\star \star \star}}\end{array}$ \\
\hline $\begin{array}{l}\text { No Apprenticeship, with Abitur } \\
\text { (dummy: } 1 \text { = yes) }\end{array}$ & $\begin{array}{l}0.132 \\
{[6.77]^{\star * \star}}\end{array}$ & $\begin{array}{l}0.185 \\
{[8.37]^{\star \star \star}}\end{array}$ & $\begin{array}{l}0.207 \\
{[5.40]^{\star \star \star}}\end{array}$ & $\begin{array}{l}0.243 \\
{[5.07]^{\star \star \star}}\end{array}$ \\
\hline Apprenticeship and Abitur & 0.261 & 0.243 & 0.224 & 0.223 \\
\hline
\end{tabular}




\begin{tabular}{|c|c|c|c|c|}
\hline (dummy: 1 = yes) & {$[18.74]^{\star \star \star}$} & {$[16.08]^{\star \star \star}$} & {$[7.70]^{\star \star \star}$} & {$[9.03]^{\star \star \star}$} \\
\hline Technical college degree & 0.419 & 0.383 & 0.355 & 0.341 \\
\hline (dummy: 1 = yes) & {$[29.15]^{\star \star \star}$} & {$[24.72]^{\star \star \star}$} & {$[12.34]^{\star \star \star}$} & {$[11.73]^{\star \star \star}$} \\
\hline University degree & 0.491 & 0.435 & 0.400 & 0.396 \\
\hline (dummy: 1 = yes) & {$[30.64]^{\star \star \star}$} & {$[27.51]^{\star \star \star}$} & {$[12.47]^{\star \star \star}$} & {$[10.42]^{\star \star \star}$} \\
\hline Education unknown & 0.027 & 0.016 & -0.041 & -0.072 \\
\hline (dummy: 1 = yes) & {$[0.61]$} & [0.53] & [1.13] & {$[1.80]^{\star}$} \\
\hline Master craftsman, foreman & 0.177 & 0.167 & 0.147 & 0.139 \\
\hline (dummy: 1 = yes) & {$[21.65]^{\star \star \star}$} & {$[19.57]^{\star \star \star}$} & {$[6.39]^{\star \star \star}$} & {$[5.76]^{\star \star \star}$} \\
\hline Constant & 3.214 & 3.261 & 4.427 & 4.245 \\
\hline & {$[45.87]^{\star \star \star}$} & {$[66.71]^{\star \star \star}$} & {$[20.38]^{\star \star \star}$} & {$[19.00]^{\star \star \star}$} \\
\hline Observations & $1,270,089$ & 709,536 & 124,062 & 78,420 \\
\hline Employees & 351,157 & 118,256 & 30,588 & 13,070 \\
\hline Plants & 3,196 & 2,745 & 96 & 96 \\
\hline $\mathrm{R}^{2}$ & 0.622 & 0.600 & 0.681 & 0.696 \\
\hline \multicolumn{5}{|c|}{$\begin{array}{l}\text { Regressions also include } 36 \text { sectoral dummies, } 9 \text { urbanisation dummies, } 15 \text { regional } \\
\text { dummies, } 11 \text { year dummies as well as } 5 \text { dummies for the respective periods t. |t|-statistics in } \\
\text { parentheses, based on robust standard errors adjusted for clustering at the plant-level. Full } \\
\text { sample refers to all observations with no missing values in the covariates. Matched sample } \\
\text { refers to observations of employees from plants which have been selected via nearest } \\
\text { neighbor propensity score matching, where the propensity score has been obtained from a } \\
\text { probit on export-starting. All comprise stayers (workers which work for the respective plant in } \\
\text { all six years of the data window) as well as employees which join/leave the plant during the } \\
\text { observed six years. }\end{array}$} \\
\hline
\end{tabular}




\section{Appendix}

Table A1: Determinants of export-starting, probit estimation; Germany (Dependent variable is a dummy for export starters: 1 = yes)

\begin{tabular}{|c|c|c|}
\hline Explanatory variables & Coefficient & Z-value \\
\hline Logarithm of average wage & 1.363 & {$[2.77]^{\star \star \star}$} \\
\hline Logarithm of total sales per employee & 0.093 & {$[0.67]$} \\
\hline $\begin{array}{l}\text { Logarithm of establishment size } \\
\text { (number of employees) }\end{array}$ & 0.952 & {$[3.24]^{\star \star \star}$} \\
\hline $\begin{array}{l}\text { Squared logarithm of establishment } \\
\text { size }\end{array}$ & -0.067 & {$[2.17]^{\star \star}$} \\
\hline Works council (dummy: 1= yes) & 0.173 & [0.73] \\
\hline \multicolumn{3}{|l|}{$\begin{array}{l}\text { Collective agreement (reference: no } \\
\text { collective agreement) }\end{array}$} \\
\hline at sectoral level (dummy: $1=$ yes) & -0.422 & {$[1.92]^{\star}$} \\
\hline at firm level (dummy: 1= yes) & 0.129 & [0.49] \\
\hline $\begin{array}{l}\text { Plant belongs to a larger unit } \\
\text { (dummy: } 1=\text { yes) }\end{array}$ & -0.118 & [0.51] \\
\hline $\begin{array}{l}\text { New production technology } \\
\text { (dummy: } 1 \text { = yes) }\end{array}$ & 0.083 & {$[0.42]$} \\
\hline Eastern Germany (dummy: 1= yes) & 0.744 & {$[2.53]^{\star \star}$} \\
\hline Average age of employees (in years) & -0.275 & [1.39] \\
\hline Average age squared (divided by 100 ) & 0.322 & [1.28] \\
\hline Average tenure of employees & 0.053 & {$[0.60]$} \\
\hline $\begin{array}{l}\text { Average tenure squared (divided by } \\
\text { 100) }\end{array}$ & -0.452 & {$[0.77]$} \\
\hline \multicolumn{3}{|l|}{$\begin{array}{l}\text { Proportion within total workforce of } \\
\text { plant: }\end{array}$} \\
\hline Female workers & 0.545 & [1.22] \\
\hline $\begin{array}{l}\text { Workers with } \\
\text { apprenticeship, no Abitur }\end{array}$ & -0.434 & {$[1.26]$} \\
\hline $\begin{array}{l}\text { Workers without } \\
\text { apprenticeship, with Abitur }\end{array}$ & 3.935 & {$[0.72]$} \\
\hline $\begin{array}{l}\text { Workers with } \\
\text { apprenticeship and Abitur }\end{array}$ & 0.18 & {$[0.17]$} \\
\hline $\begin{array}{l}\text { Workers with technical } \\
\text { college degree }\end{array}$ & -0.14 & {$[0.14]$} \\
\hline $\begin{array}{l}\text { Workers with university } \\
\text { degree }\end{array}$ & 0.026 & [0.03] \\
\hline Master craftsman & 0.483 & {$[0.25]$} \\
\hline Constant & -10.453 & {$[]$.} \\
\hline Number of plants & 2,182 & \\
\hline$X^{2}(48)$ & 164.65 & 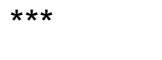 \\
\hline Pseudo- $R^{2}$ & 0.346 & \\
\hline
\end{tabular}

All covariates dated at $\mathrm{t}=1$. Regressions also include sectoral and year dummies. $* / \star \star / \star \star *$ denotes statistical significance at the $10 / 5 / 1 \%$ level. Number of plants is lower than the respective figure reported in Tables $2 / 3(3,196)$, since the latter also comprise plants which have missing values in the first year (and thus do not enter the probit regression), but with complete information in at least one of the other years. 
Table A2: Mean values of variables for export starters and non-exporters

\begin{tabular}{|c|c|c|c|c|c|c|}
\hline \multirow[b]{2}{*}{ Variable $^{\mathrm{b}}$} & \multicolumn{3}{|c|}{ All plants } & \multicolumn{3}{|c|}{ Matched plants } \\
\hline & $\begin{array}{c}\text { Export } \\
\text { starters } \\
(N=56)^{c}\end{array}$ & $\begin{array}{l}\text { Non- } \\
\text { exporters } \\
(N= \\
3,067)^{c}\end{array}$ & P-value ${ }^{a}$ & $\begin{array}{l}\text { Export } \\
\text { starters } \\
(N=48)\end{array}$ & $\begin{array}{l}\text { Non- } \\
\text { exporters } \\
(N=48)\end{array}$ & P-value ${ }^{a}$ \\
\hline Logarithm of average wage & 4.317 & 4.042 & 0.00 & 4.287 & 4.352 & 0.27 \\
\hline $\begin{array}{l}\text { Logarithm of total sales per } \\
\text { employee }\end{array}$ & 12.294 & 11.837 & 0.00 & 12.315 & 12.338 & 0.89 \\
\hline $\begin{array}{l}\text { Establishment size (number } \\
\text { of employees) }\end{array}$ & 4.405 & 3.068 & 0.00 & 4.428 & 4.590 & 0.62 \\
\hline $\begin{array}{l}\text { Works council } \\
\text { (dummy: } 1=\text { yes) }\end{array}$ & 0.554 & 0.234 & 0.00 & 0.542 & 0.563 & 0.84 \\
\hline $\begin{array}{l}\text { Collective agreement at the } \\
\text { sectoral level } \\
\text { (dummy: } 1=\text { yes) }\end{array}$ & 0.500 & 0.504 & 0.95 & 0.479 & 0.625 & 0.15 \\
\hline $\begin{array}{l}\text { Collective agreement at the } \\
\text { firm level (dummy: } 1=\text { yes) }\end{array}$ & 0.143 & 0.106 & 0.44 & 0.167 & 0.167 & 1.00 \\
\hline $\begin{array}{l}\text { Plant belongs to a larger unit } \\
\text { (dummy: } 1=\text { yes) }\end{array}$ & 0.232 & 0.124 & 0.06 & 0.208 & 0.208 & 1.00 \\
\hline $\begin{array}{l}\text { New production technology } \\
\text { (dummy: } 1 \text { = yes) }\end{array}$ & 0.768 & 0.704 & 0.27 & 0.771 & 0.792 & 0.81 \\
\hline $\begin{array}{l}\text { Eastern Germany (dummy: } \\
1=\text { yes) }\end{array}$ & 0.446 & 0.504 & 0.40 & 0.479 & 0.417 & 0.54 \\
\hline $\begin{array}{l}\text { Average age of employees } \\
\text { (in years) }\end{array}$ & 39.933 & 38.589 & 0.04 & 39.793 & 39.935 & 0.86 \\
\hline $\begin{array}{l}\text { Average Tenure of } \\
\text { employees }\end{array}$ & 16.160 & 15.246 & 0.08 & 16.005 & 16.092 & 0.89 \\
\hline \multicolumn{7}{|l|}{$\begin{array}{l}\text { Proportion within total } \\
\text { workforce of plant: }\end{array}$} \\
\hline Female workers & 0.264 & 0.375 & 0.00 & 0.275 & 0.251 & 0.59 \\
\hline $\begin{array}{l}\text { Workers with } \\
\text { apprenticeship, no Abitur }\end{array}$ & 0.007 & 0.003 & 0.18 & 0.005 & 0.007 & 0.56 \\
\hline $\begin{array}{l}\text { Workers without } \\
\text { apprenticeship, with Abitur }\end{array}$ & 0.032 & 0.024 & 0.33 & 0.036 & 0.035 & 0.95 \\
\hline $\begin{array}{l}\text { Workers with } \\
\text { apprenticeship and Abitur }\end{array}$ & 0.050 & 0.024 & 0.04 & 0.043 & 0.064 & 0.39 \\
\hline $\begin{array}{l}\text { Workers with technical } \\
\text { college degree }\end{array}$ & 0.062 & 0.027 & 0.10 & 0.045 & 0.048 & 0.88 \\
\hline $\begin{array}{l}\text { Workers with university } \\
\text { degree }\end{array}$ & 0.021 & 0.023 & 0.78 & 0.024 & 0.031 & 0.51 \\
\hline Master craftsman & 0.264 & 0.375 & 0.00 & 0.275 & 0.251 & 0.59 \\
\hline
\end{tabular}

